Jakub de Chyży (D) https://orcid.org/0000-0002-5742-3835

Touro University College, Freie Universitat,

Akademia Humanistyczna im. A. Gieysztora (doktorant)

jakub-dechyzy@wp.pl

\title{
Sephardim and their language: Judeo-Spanish or Ladino?
}

\begin{abstract}
The aim of this work is to describe the most relevant features of the languages spoken by the Sephardic Jews, focusing on Judeo-Spanish and Ladino. These two languages have been treated as a single language, even though Judeo-Spanish was a day-to-day communication language, and Ladino a calque-language used to translate religious texts from Hebrew during the $16^{\text {th }}$ and $17^{\text {th }}$ centuries.

A brief overview of Sephardim historical background is necessary in order to understand who the Sephardim are, the development of their language and literature, and to discuss anything related to them.
\end{abstract}

Keywords: Sephardic Jews, Judeo-Spanish, Ladino

\section{Historical background}

Sephardim are the descendants of Jews who had at one time lived on the Iberian Peninsula (Spain and Portugal), and who were expelled from Spain in 1492 by the Catholic Monarchs, Ferdinand and Isabel, under the Alhambra Decree (Peters, 1995: 9-34), and persecuted by the Spanish Inquisition.

Jews initially settled in Spain during Roman times and endured life there during Christian rule. During the fourth century C.E. the Jewish population in the Iberian Peninsula was considerable even though life was not that easy for them. The Canons of the Council of Elvira, for example, prohibited marriages and other intercourse with Jews. However, their more serious difficulties began during the Visigothic period, especially from the conversion to Catholicism of the King Recaredo I in 589, and the oppressive anti-Jewish measures promulgated in the Councils of Toledo. 
However glorious and tragic often at the same time the history of Spain was, what must be remembered is that Spain was the only place in the Western world where the three cultures the Christian, the Muslim and the Jewish coexisted in harmony and prosperity. This period called in Spanish la convivencia, the Coexistence, begun after the Muslim invasion in 711 and lasted for seven centuries. The Sephardic culture reached its full flourishing under Islam, enjoying a period of splendour. The Christian Reconquest of Spain though, during the twelfth century, brought them gradually back under Christian rule. The Coexistence sadly came to an end in the same year, when Columbus sailed to China and ended up in the Caribbean.

In 1492, the notorious Father Tomas de Torquemada, the grand inquisitor of the Spanish Inquisition started to pressure the Catholic Monarchs to issue a decree of expulsion of the Jewish community from Spain on the grounds of fear, that as long as the Jews remained in Spain, they would influence recent Jewish converts to Christianity to continue practicing Judaism. Once the Muslim forces in Granada have been defeated by the Spanish Army, which restored the whole of Spain to Christian rule, thus accomplishing the most important objective - country's unification, Ferdinand and Isabella concluded that the Jews too were expendable and issued the expulsion decree on March 30.

The decree was to take effect in 4 months, a period during which the Jews were forced to liquidate their properties, business and goods at incredibly low prices. Some Jews, in the face of the menace of the exile, decided to accept Christianity in order to remain in the Iberian Peninsula Even though some of them became real conversos (converts), many of the conversos who stayed in the country were Crypto-Jews, and kept on practising their rituals and traditions in secret.

Already in the preceding period of nearly a hundred years the Jews of Sefarad suffered injustice from the Crown due to failed promises to protect their property. The picture below is representative of the oppression that was to evolve into a truly ugly destiny of torture, execution and expulsion.

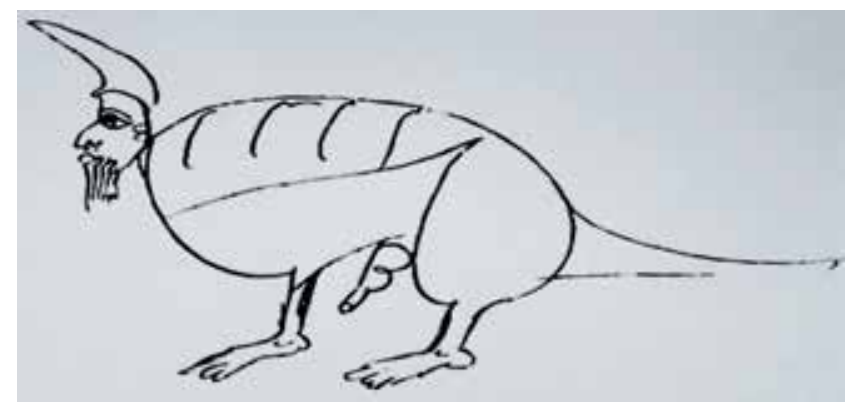

Figure 1. The caricature of a circumcised rat, with beard and hat characteristic of those worn by Jews in the fourteenth century, was discovered sketched on the blank pages in the back of a fifteenth century book from the Justicia Civil of Valencia. It is assumed that the unknown artist was a Christian visitor, portraying his perception of Jews as unclean animals, meriting scorn and ridicule 
As Christopher Columbus will remember it in his diary, in the same month when the Monarchs issued the edict that all Jews should be driven out of the kingdom and its territories, he was given the order to undertake his expedition of discovery to the Indies. On July 30 1492, some 200,000 people, nearly the entire Jewish community, was expelled from Spain.

The Jews who decided to leave the Iberian Peninsula left for the North of Africa (mostly today's Morocco and Algeria), the Ottoman Empire (mostly Salonika, Constantinople and Sarajevo), Bayonne, Italy, Northern Europe (mostly England or Flanders), and later on to Holland. Eventually, many of the Crypto-Jews who remained in Iberia, fearing Inquisition and the hard conditions they lived under, decided to move out and join the Jews who were in Exile.

\section{The key, nostalgia of the lost land}

The sudden expulsion of the Jews was undoubtedly a traumatic shock for all of them. They were given only four months to leave the country if they did not convert to Christianity. The ones who left their land behind took with them the keys of their homes and their synagogues, convinced that the exile would be temporary and they would return one day. Those keys, although most families no longer have them anymore, became a symbol of their rich Spanish heritage, of their beloved and lost land.

In 1924 Miguel Primo de Rivera enacted a law restoring Spanish citizenship to every Sephardi who claimed it, which was very useful to many Jews during World War II and the Bosnian War. In 1992, the Spanish king Juan Carlos I, wearing a skullcap in a ceremony marking the 500th anniversary of the Alhambra Decree, said: "Sefarad is no longer nostalgia, but a place where Jews should not be told to feel as if at home, because Hispano-Jews are at home in Spain".

On $6^{\text {th }}$ June 2014, the Spanish Government passed a law (ep00.epimg.net/descargables/2014/06/06/d2568a932335d0680fa9107ee72ef7a6.pdf), which allows descendants of Sephardic Jews to get Spanish nationality. The minister of Justice, Alberto Ruiz Gallardón, declared that "this law is a real historic reparation of, I dare say, the biggest mistake in Spanish history" http://www.nytimes.com/2014/03/20/world/europe/many-seek-spanish-citizenship-offered-to- sephardic-jew-s.html). Gallardón added: "many kept the keys of the house from which they were expelled, now they have the door open." (http://www. reuters.com/article/2014/02/07/us-spain-jews-idUSBREA161GQ20140207).

\section{Language}

For many centuries Jews have lived in physical, social, cultural and even linguistic isolation. This explains why the Medieval Ibero-Romance languages used by them were not exactly the same as those used by their Christian neighbours, although they did not differ that much except for some words related to religion. Sephardim spoke what nowadays we call Judeo-español or Ladino, two different terms used in reference to the same language and the difference between which is explained below: 
Judeo-español is a Romance language derived from old Spanish, a term used by Romance philologists and linguists to indicate the linguistic varieties written and spoken by the Sephardim. This language includes many components of the Old Romance languages spoken at that time in Sefarat, such as Catalan, Galician-Portuguese, Aragonese, Astur-Leones and Mozarabic, as well as some Hebrew, Aramaic and Arabic words.

Ladino, on the other hand, is a calque language of Hebrew, used to translate liturgical texts into Spanish, being not a day-to-day communication language. The word Ladino, which comes from the Spanish latino [Latin], was a term used to name Moors and Jews who spoke the Christian language.

The features of this calque-language and the literal translation, according to Paloma Diaz-Mas, "produces a completely artificial language, one that is often unintelligible if the reader does not know the Hebrew source of the 'ladinised' passage" (Díaz-Mas, 1992: 76). As an example, we find that the Spanish term Dios [God] is replaced by El Dio, as the Spanish ending -s is normally used for plural, and saying Dios would indicate polytheism. On the other hand, the word vidas [lives] is always written in plural, as well as the word aguas [waters], which in Hebrew is hayim and mayim respectively; as in Hebrew these words have the plural ending, they were translated as plural nouns. Many Arabic words were used as well, as phonetically Hebrew and Arabic use similar sounds that did not exist in Spanish at the time. For example, we find the Arabic word alhad instead of domingo [Sunday]; Domingo was the day of God for Christians, but for the Jewish week the Holy Day is Shabbath. Even though Ladino was used in the $16^{\text {th }}$ and $17^{\text {th }}$ centuries in order to translate religious texts from Hebrew, nowadays Ladino is a term widely adopted to name the language used by Sephardim, especially used in Israel.

The language spoken by Sephardim, besides being called Ladino and Judeo-español, is also known as Judezmo (used mostly by linguists and in the academic field), Sefardi, Spanyol or Español nuestro (making a distinction between this language and the Español (Spanish) spoken in Spain and Latin America), Judio or Jidio, and Haketia (the variety of Judeo-Spanish spoken in Northern Africa). Quoting Diaz-Mas, the Sephardim regularly called their spoken language Judezmo or Español to distinguish it from Ladino, the calque-language. However, Ladino has lately come to be used as a synonym for Judezmo. The name Judeo-Spanish is a recent scholarly creation (Díaz-Mas, 1992: 77).

Ladino was written in the Hebrew alphabet, in Rashi script, or in Solitro for most of its lifetime, and it was not until recent times that it has been written using Latin alphabet. When the Jews were expelled from Spain in 1492, they took with them different varieties of Iberian- Romance languages, depending on their region of origin. In their new homes, Spanish-speaking Jews found themselves pretty isolated in places where their new neighbours were using Greek, Italian, Arabic, Turkish, French or Flemish as a communication language, but this allowed the Jews to keep their own language. Nevertheless, we have to point out that in countries like Italy, England, France and the Low Countries, Sephardim ended up adopting the language of their neighbours and stopped using their own.

Judeo-español, then, cut off from the influence of the Spanish spoken in Spain, which became modernised, kept its $15^{\text {th }}$ century roots, and evolved in a different way. It borrowed many words from Hebrew, such as anav [obedient] or atakanear [to arrange]; Arabic, such as atemar [termi- 
nate] or alforría [freedom]; Turkish, such as kolay [easy] or parás [money]; Italian, such as ma [but] or libero [free]; French, such as rolo [role] or jugador [actor]; and Greek. It also included hundreds of old Spanish words which do not exist anymore in the current Spanish. The different changes of the language were influenced by the countries and cultures where Sephardim settled.

\section{Literature}

Literature written in Ladino started in Spain before the expulsion, where the Jewish intellectual elite was involved in the Spanish culture. One of the best known authors during the $14^{\text {th }}$ century was Rab Don Santob de Carrión, who wrote the book "Proverbios morales". This book, found in the Cairo Geniza, was ladinised during the $15^{\text {th }}$ century and copied in Hebrew characters, as found in these few verses below:

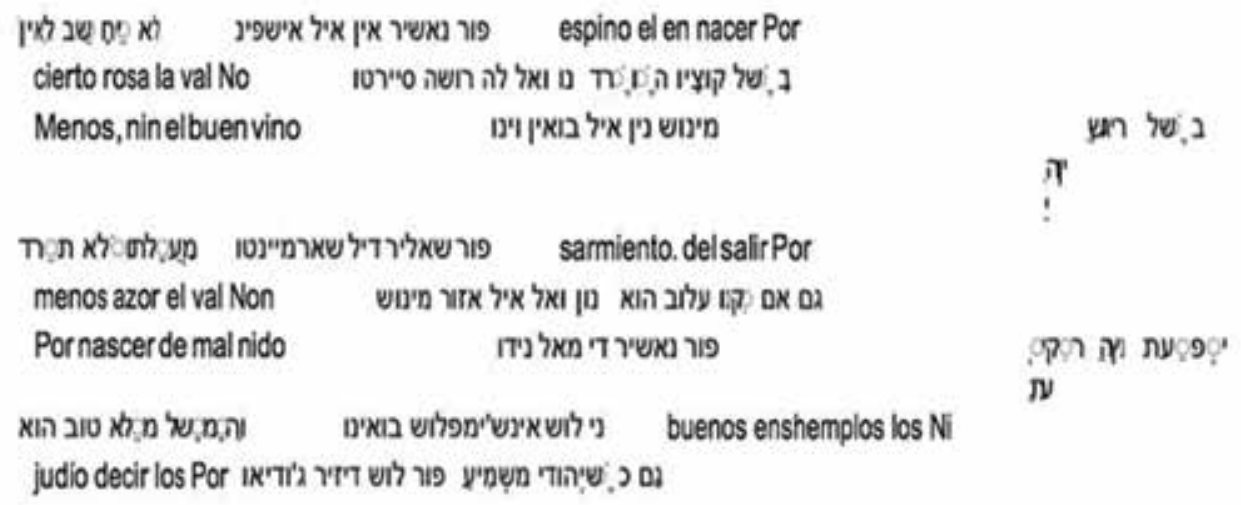

Figure 2. Proverbios morales, by Rab Don Santob de Carrión, XIV century Source: http://btjerusalem.com/aspamiac.htm.

We find three categories of Ladino literature: translations of sacred texts (such as the Hebrew Bible, the High Holiday prayerbook and the Passover Haggadah); rabbinic literature; and folk tales, fables, proverbs, poems, and short stories.

During the $16^{\text {th }}$ and $17^{\text {th }}$ centuries, many Crypto-Jews emigrated to Holland, enriching economically and culturally the communities they joined. Therefore, Diaz-Mas states, "it is not surprising that the Low Countries, together with Italy, would become an important centre of Jewish publication where numerous books were printed in Spanish" (Díaz-Mas, 1992: 37). While Portuguese was the language used in daily basis communication, Spanish remained as the language of publication and study. Among those intellectuals, Baruch Spinoza, Shelomo ben Verga and David Pardo are worth mentioning. On the other hand, the expelled Jews who arrived in the Ottoman Empire started printing books in Hebrew and Ladino. One of the first books printed in Ladino was Rejimiento de la vida by Rabbi Moshé Almosnino, published in Salonika in 1564, and written as a guide for his son about how a man should live this life without neglecting his duties. 


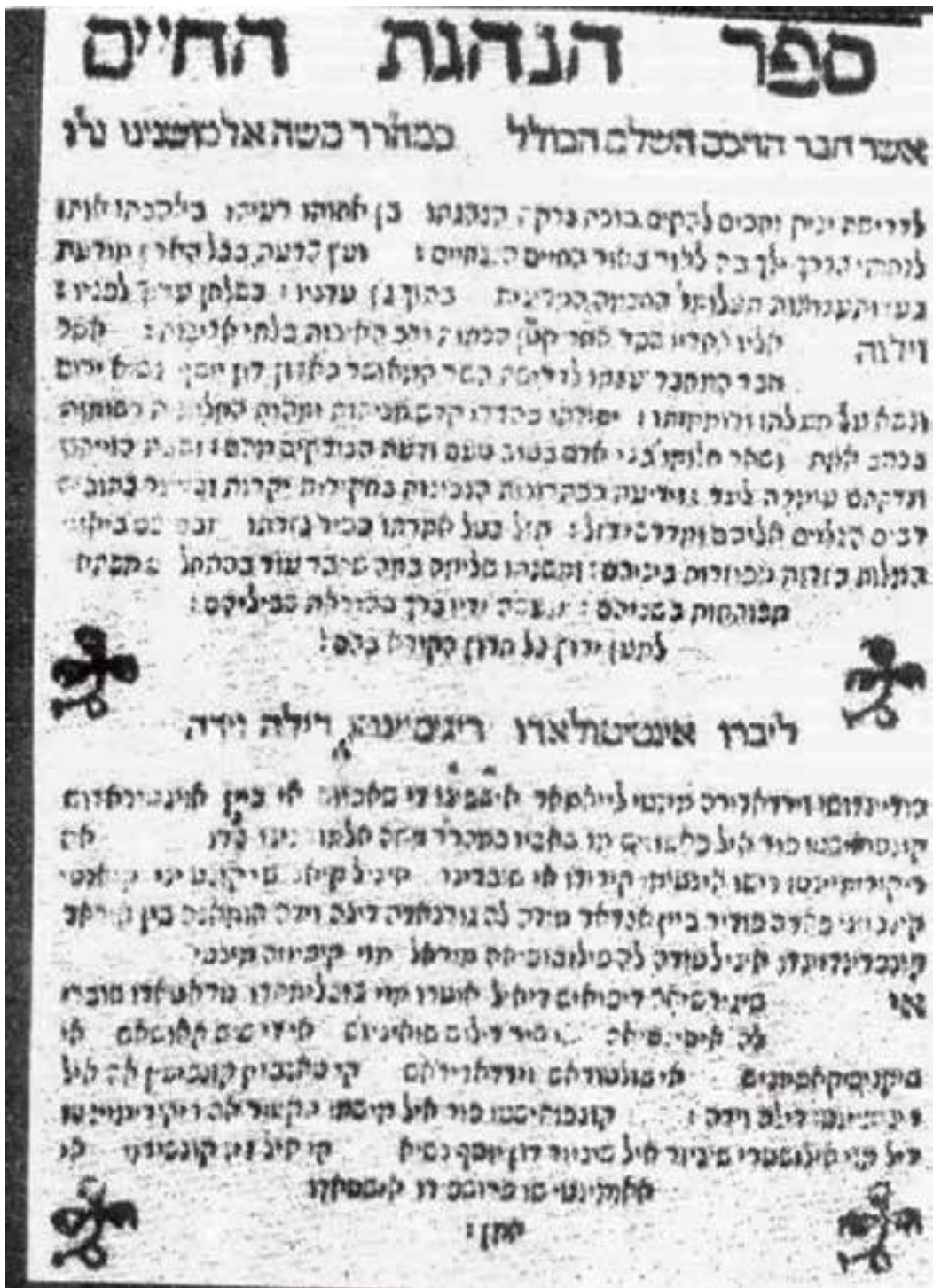

Figure 3. Rejimiento de la vida, by Rabbi Moshé Almosnino, Salonika 1564 Source: btjerusalem.com/aspamiac.htm.

Also in Salonika, in 1568, the book Mesa de el Alma by Joseph Qaro ben Ephraim was published. It was written in order to enable the women and the men who did not know Hebrew to become acquainted with the religious rules and ceremonies. A few years later, in 1609, Moseh Altharas published in Italy a revised edition of Joseph Qaro's book, called Libro de mantenimiento de la alma: en el qual se contiene el modo con que se à de regir el Iudio en todas sus actiones. The translation into Ladino, by Guedaliá Ibn Yahiá, of the book Dialoghi di Amore, published in Italy in 1568, in the Latin alphabet, is also remarkable. 


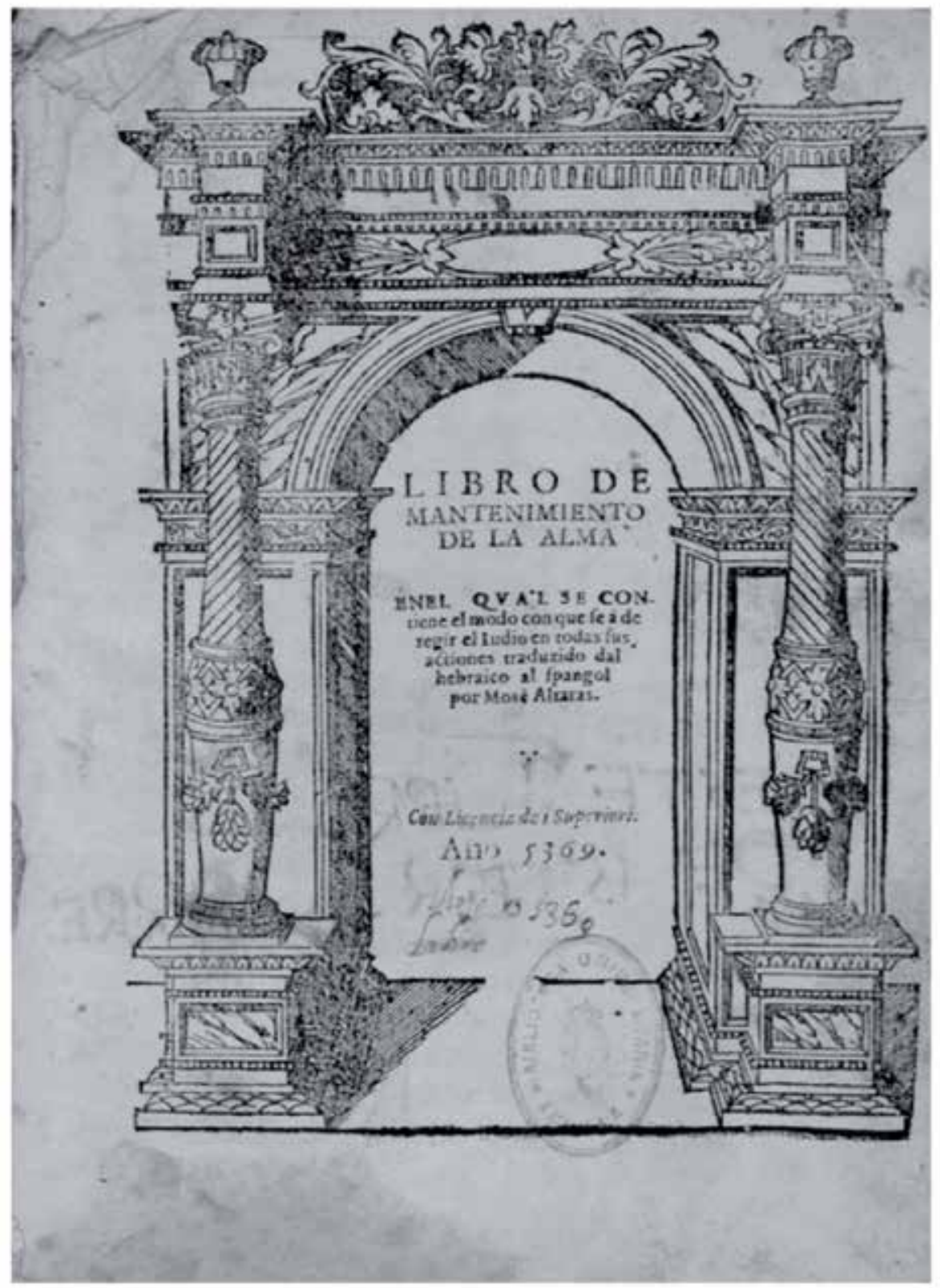

Figure 4. Libro de mantenimiento de la alma: en el qual se contiene el modo con que se à de regir el Iudio en todas sus actiones, Italy 1609

Source: http://fondosdigitales.us.es/fondos/libros/4255/8/libro-de-mantenimiento-de-la-alma-en-elqual-se- contiene-el-modo-con-que-se-de-regir-el-iudio-en-todas-sus-actiones/. 


\section{ทาטNp ibesp}

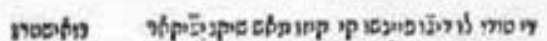

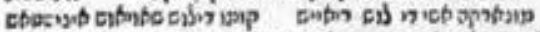

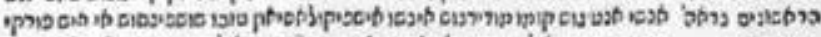
מיק

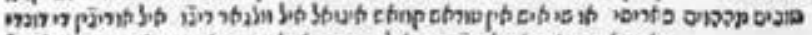

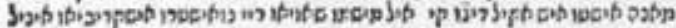

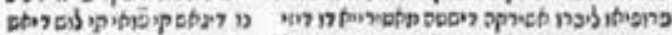
vebontpry twajen

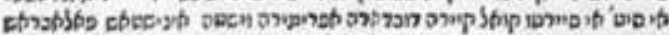

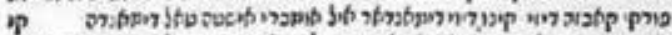

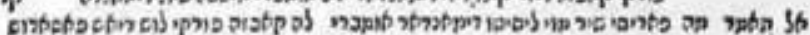

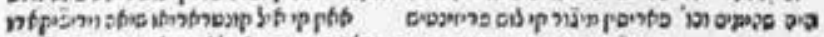

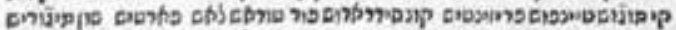

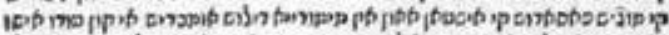
D) a

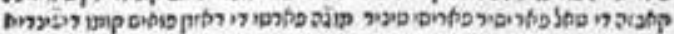

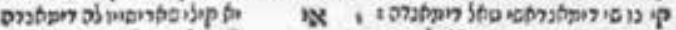

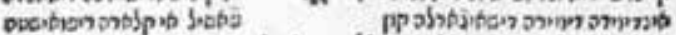

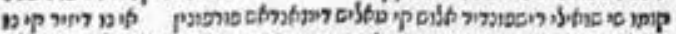

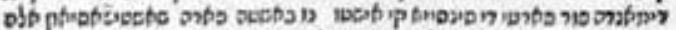

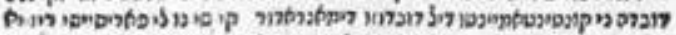

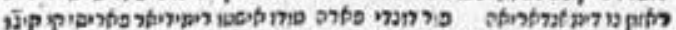

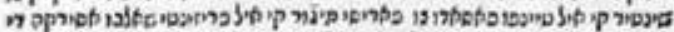

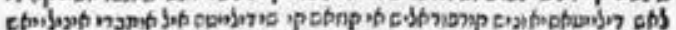

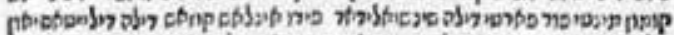

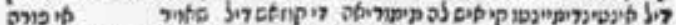

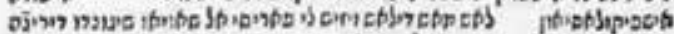

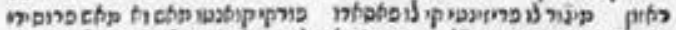

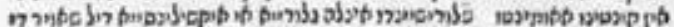

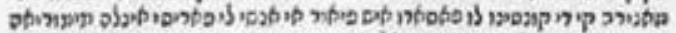

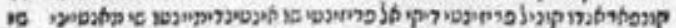

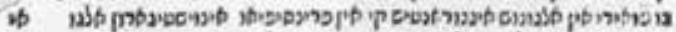

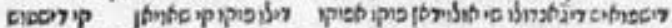

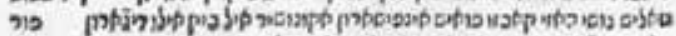

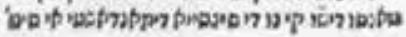

Figure 5. Manuscript in Ladino of Dialoghi di Amore

Source: btjerusalem.com/aspamiac.html.

The tradition of translating the Bible literally (calque-language) starts before the Jews were expelled from Spain. During the $16^{\text {th }}$ century two translations of the Bible into Ladino appeared: Pentateuco, published in Constantinople in 1547, in Hebrew characters; and Ferrara Bible, published in Italy in 1553, in Latin letters. Both of them were followed by more Bible translations during the next centuries. 
במדכר

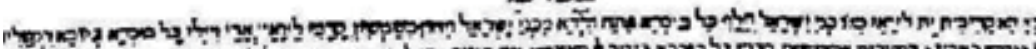
घ g.

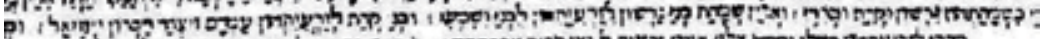
w.

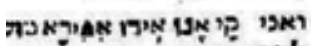

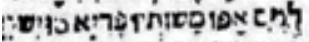

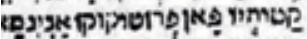
צ' "

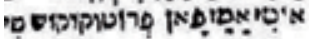
จาด טי

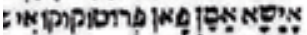

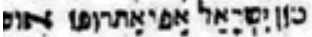

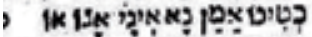
צtrex ip ivip?

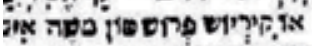

ט !

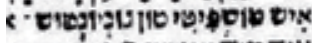

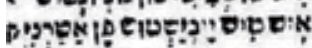

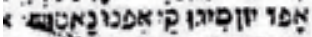

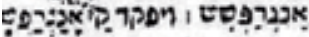
ฉอง ו

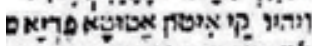

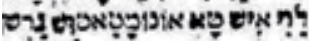
? " จุ

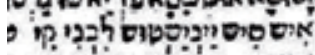

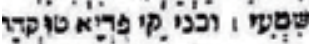
e o.py r

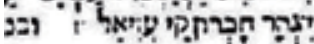
?

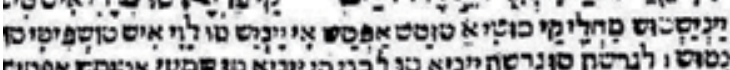

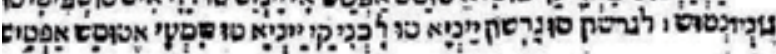

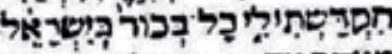

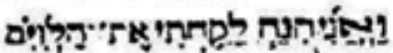

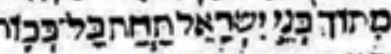

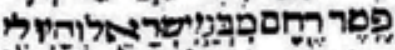

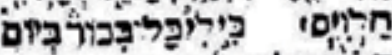

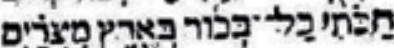
ㄴ. Q :

ตำง

יב:

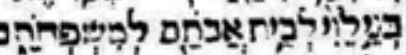
ר : חלק.

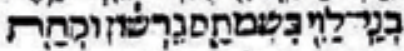

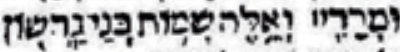

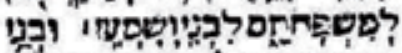
ᄀigy

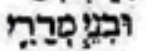

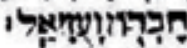

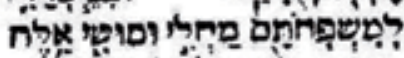
!

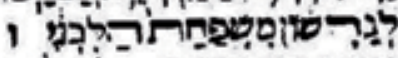

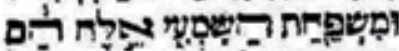

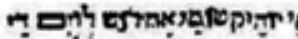
p.

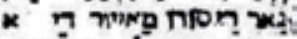

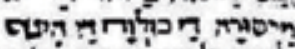
ס

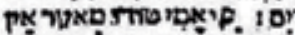

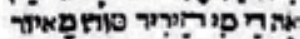

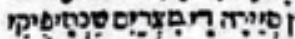

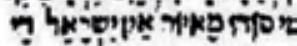

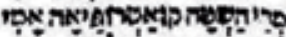

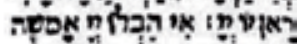
4 พาร

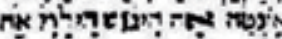

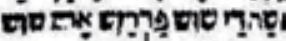
ตK.

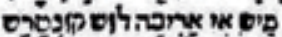
I

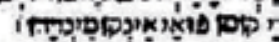

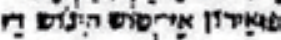

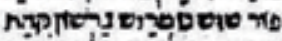

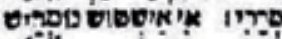
o

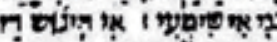
n.

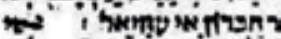

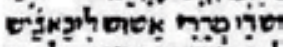

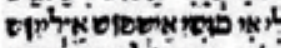

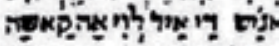
roys 1 ing

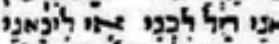

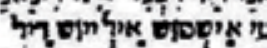

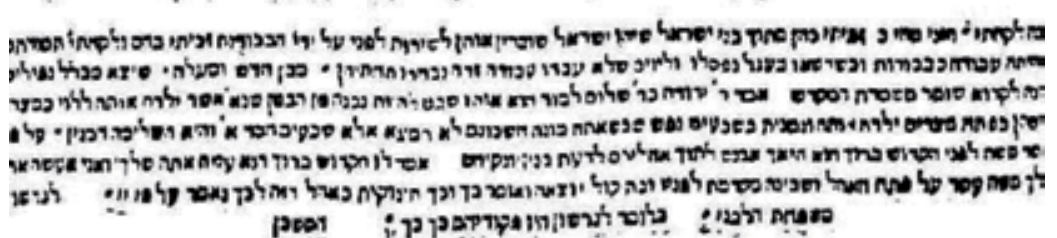

Figure 6. Pentateuco with Ladino language (right column), Constantinople 1547 Source: Ibidem.

One of the earliest poetic works in Ladino was Coplas de Joseph ha-Zaddik by Abraham Toledo (Constantinople, 1732), and the first Hebrew grammar in Ladino was published in Vienna in 1823, followed by many others. 
In 1855, also in Constantinople, a Hebrew-Ladino Biblical Dictionary was also published. The publication of Dictionnaire du Judéo-Espagnol in Madrid in 1977 was important as well. It was written by Joseph Nehama (ca. 1880-1971), Greek educator and historian, and published six years after his death, in 1977, thanks to the collaboration of Jesus Cantera.

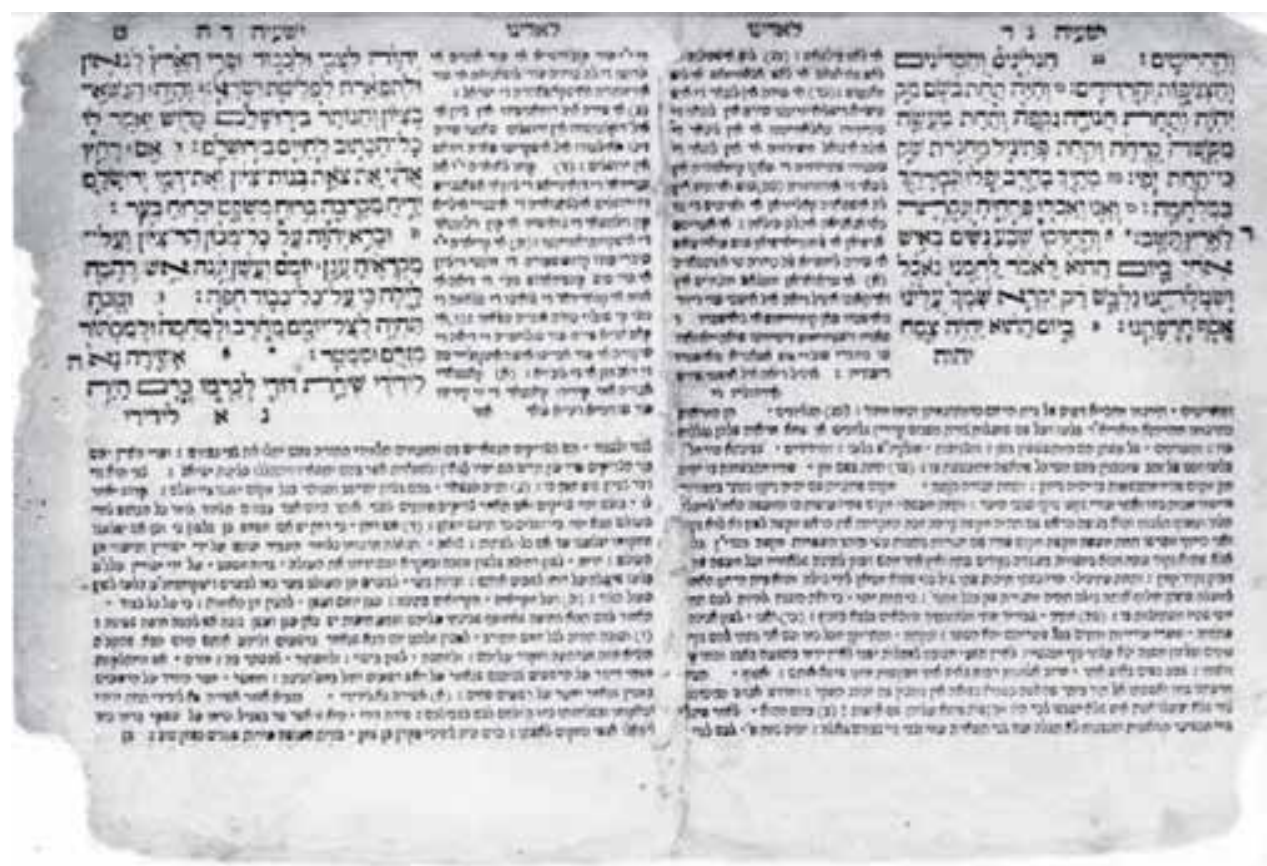

Figure 7. Psalms (salmos) with Ladino language, translated by Abraham Asa, Constantinople 1745

Source: Nehama, Cantera Ortiz de Urbina, 1977.

We have to mention Me'am Lo'ez, which, in words of Tamar Alexander-Frizer, "is the most important work written in Ladino". (T. Alexander-Frizer, 2002: 45) The curious aspect of this book is that it was written by different authors between 1730 and 1864, as if it were an encyclopaedia. AlexanderFrizer adds that Me' am Lo'ez was "a bridge between Hebrew sources and the Ladino reader, between written and oral literatures" (Ibidem: 64) which was "aimed at making Hebrew sources available to the Sephardic ethnic group in their own language, Ladino." (Ibidem: 45)

According to Samuel G. Armistead, Hispanic Jews took into exile and cultivated a large amount of oral literature, which included "narrative ballads (romansas), lyric songs (cantigas), cumulative songs, prayers and medicinal charms, riddles (endevinas), proverbs (refranes), and folktales (consejas)" (www.sephardifolklit.org/flsj/OLSJ). Armistead adds two partially oral genres, such as "complas (paraliturgical poetry: popular, sometimes traditionalised, religious or didactic songs) and plays, originally staged to commemorate 
important holidays". (Ibidem) Although we can find a large number of songs in Ladino, we should highlight the folk song Coplas de Purim, dated around 1700 its lyrics can be found below, and also Coplas Nuevas, published in Salonica in 1868.

\section{COPLAS DE PURIM}

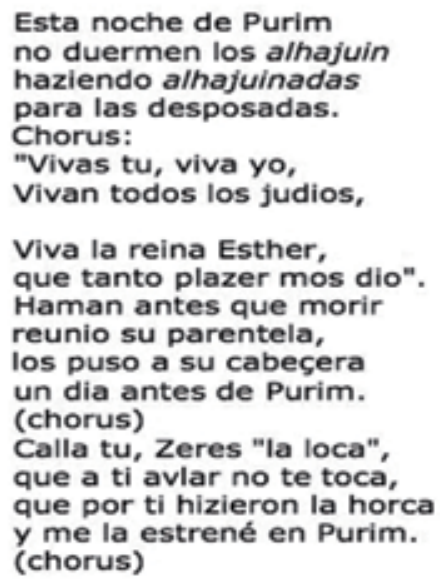

Amparo-te con tus manos, aproves muestros hermanos ha turcos $y$ ha cristianos aunque no mos pueden veer. (chorus)

Indianas muy bien assadas, Pinyonada y almendras,

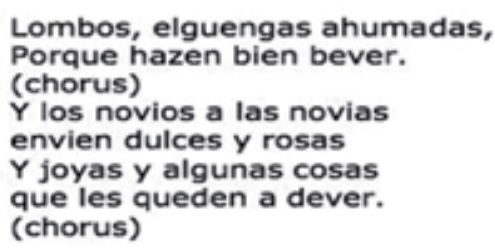

Figure 8. Coplas de Purim, 1700

Source: https://www.youtube.com/watch?v=OVYE10U4SNc.

Sephardim provide us with many proverbs as well, many of which are still being used currently in Spain, such as: 


\begin{tabular}{|c|c|}
\hline \multirow[t]{2}{*}{ Ladino: } & Dime con con quén andas; te diré quén sos. \\
\hline & Dime kon kién fueres i diréte kién eres \\
\hline Spanish: & Dime con quién andas y te diré quien eres \\
\hline English: & Tell me who you go around with and I'll tell you who you are. \\
\hline \multirow[t]{2}{*}{ Ladino: } & Aqueyos polvos truxeron estos lodos. \\
\hline & Kon esos polvos se hizieron estos lodos. \\
\hline Spanish: & De aquellos polvos, vinieron estos lodos \\
\hline English: & That dust brought, or made, this mud. \\
\hline \multirow[t]{2}{*}{ Ladino: } & Antes que te cazes, mira lo que hazes. \\
\hline & Antes ke te kases, mira lo ke hazes... \\
\hline Spanish: & Antes de que te cases, mira lo que haces. \\
\hline English: & Watch what you do before you get married \\
\hline \multirow[t]{2}{*}{ Ladino: } & A gran' a grano, hinche la gayina el papo. \\
\hline & Grano a grano, hinche la gallina el papo. \\
\hline Spanish: & Grano a grano, hincha la gallina el papo. \\
\hline English: & One seed at a time, a hen fills its craw. \\
\hline
\end{tabular}

Figure 9. Judeo-Spanish Proverbs

Source: Tamar, 2004: p. 17-19, p. 20-22, 25. See also: Lévy, 1969.

\section{Language in the Holocaust and the current situation}

Nowadays, though, the reality that Judeo-español or Ladino is facing is very different, and its future unknown, as it is considered an endangered language which may become extinct in the near future. The Holocaust, besides the terrible human loss, represented the loss of $90 \%$ of Ladino-speaking Jews and a major crisis for this language. The systematic annihilation of the European Jewry in the concentration and extermination camps is the hardest and cruellest historic event suffered by Jewish communities since the expulsion from Spain in 1492. One of the purposes of the Nazi policy was a crusade against Judaism, which culminated in approximately six million Jews being killed by Nazi Germany throughout the German Reich and on the German - occupied territories. The magnitude of the tragedy of Greek Sephardim, for example, is more than obvious, as shown in the following figures: 
Table 1. Comparison of the Greek Sephardim Population in 1941 and 1945

\begin{tabular}{|l|c|c|}
\hline \multicolumn{1}{|c|}{ Community } & Population in 1941 & Population in 1945 \\
\hline Salonica & 56,200 & 1,240 \\
\hline Cavala & 2,100 & 42 \\
\hline Corfu & 2,000 & 185 \\
\hline Rodas & 1,701 & 40 \\
\hline Jannina & 1,850 & 163 \\
\hline Drama & 1,200 & 39 \\
\hline
\end{tabular}

Source: www.um.es/tonosdigital/znum5/estudios/J-infierno.htm.

We should not forget that Salonica became the largest centre of the Sephardic Jews in Europe until the German occupation and consequent annihilation of most of this population.

The concentration camps became a melting pot of cultures and languages, and Jews (both Ashkenazim and Sephardim) were the largest ethnic group. Despite the dire living conditions in the camps, Dr. Salvador Santa Puche states that Sephardim kept their cultural tradition through music: many deportees used Sephardic songs to please the guards in order to get a bit more food ${ }^{1}$. Puche affirms that, among all the songs, one became a hymn among the deportees, called Arvoles yoran por luvyas:

\section{ARVOLES YORAN POR LUVYAS}

\section{Arvoles yoran por luvyas \\ I muntanyas por ayres \\ Ansi yoran los mis ojos \\ Por ti, kerida amante}

Torno i digo: ke va ser de mi? En tierras ajenas yo me vo murir

\section{Enfrente de mi ay un andjelo \\ kon sus ojos me mira \\ Yorar kero I no puedo \\ mi korason suspira}

Torno i digo: ke va ser de mi En tierras ajenas yo me vo murir

\section{TREES WEEP FOR RAIN}

Trees weep for rain
And mountains for air
Thus my eyes weep
For you, dear beloved.

I turn and I ask: what will become of me? In foreign lands I am destined to die.

There is an angel in front of me with your eyes he looks at me I want to cry, but cannot My heart sighs

I turn and I ask: what will become of me? In foreign lands I am destined to die.

Figure 10. Arvoles yoran por luvyas

Source: www.um.es/tonosdigital/znum5/estudios/J-infierno.htm.

It is very difficult to know how many people speak Ladino today but, according to Isaac Navón, in one way or another it seems that around 220,000 speak this language (www. tarbutsefarad.com/en/recortes-de-prensa/860-el-ladino-renace-de-sus-cenizas-y-cautiva-a-generaciones-jovenes.html). This fact is really worrying as when a community loses

${ }^{1}$ One of the Sephardic Jews who survived thanks to his amazing voice was Estrongo Nachama, nicknamed "the singer of Auschwitz". In Berlin he became the chief cantor for the Jewish community, and was awarded by the German Government for his community work. One of his achievements was a symbiosis of Sephardic and Ashkenazi elements in synagogue music. 
its language, a great part of its cultural identity is lost. A series of actions is being taken to keep this language alive, as most of the Ladino-speakers are over 50 years of age. Currently there are study centres, book-collection efforts and teacher-training programs, departments of Sephardic studies in some Universities (in Israel and abroad), and Ladino songs are getting more popular and are attracting a wider audience. In Israel, Europe and the United States, writers are struggling to keep Ladino literature alive.

In contemporary writing, we can still find the sentiment of Sephardim towards Spain, which, in the words of Alexander-Frizer, comprises "a mixture of nostalgic longing for a glorious past and the painful historical and collective memory of the great expulsion". (Alexander-Fritz, 71) Below we find an extract of a Romance written by Matilda Koen-Sarano, where this feeling becomes very clear:

ESPANYA POR SIEMPRE

Espanya por siempre
Espanya, tierra de mis abuelos,
Espanya, tierra de mis dolores,
Espanys, tierra de mis amores,
Tengo siempre en el korason.
Tus flamas ardientes
Tus streyas briyantes
Ke no pudi apuntar.
Tus lindas sivdades
Ke por siempre vo sonyar,
Tus dulses kansiones
Ke no kedo de kantar.

\section{SPAIN FOREVER}

Spain forever
Spain, oh Spain, my father's land,
Spain, oh Spain, my sorrows' land,
Spain, oh Spain, my passion's land,
You'll stay forever in my heart.
Your ardent flames ablaze,
Your ever-shining stars,
Countless in my gaze.
Your cities in their beauty
Are in my dreams for aye,
Your honeyed songs so sweet
I'll never cease to sing.

Figure 11. Romance, by Matilda Koen-Sarano

Source: www.um.es/tonosdigital/znum5/estudios/J-infierno.htm.

La Autoridad Nasionala del Ladino i su Kultura was founded in Israel in 1997 in order to preserve, safeguard and promote the Ladino language, propagate the culture and publish books written in Ladino by contemporary authors, among other things. The magazine $\mathrm{Aki}$ Yerushalayim, published jointly by the Sefarad Association and the Autoridad Nasionala del Ladino i su Kultura, is the most important newspaper published in Ladino. In Turkey, a Ladino newspaper, Şalom, is published once a week for Ladino Reader.

It is worth mentioning that in 1999 a worldwide online community of Ladino-speakers called Ladinokomunita was founded. More than 500 people participate actively, discussing topics such as Sephardic culture, history and language, using only Ladino as a communication language. These kinds of initiatives are the key to promote the use of the language and the knowledge of Sephardic History and culture. With the continuous passionate work of scholars and activists, as well as with the help of the Israeli government in language preservation, there is still hope that new generations will use Ladino as a communication language in the future. 


\section{Bibliography}

Alexander-Fritzer T. (2002), The heart is a mirror: the Sephardic folktale, Wayne State University Press, Detroit.

Brenner M. (1997), After the Holocaust: Rebuilding Jewish lives in Postwar Germany, Princeton University Press, New Jersey.

Díaz-Mas P. (1992), Sephardim: the Jews from Spain, The University of Chicago Press, LTD., London.

Lévy Isaac J. (1969), Study Prolegomena to the Study of the Refranero, Las Americas, New York.

Nehama J., Cantera Ortiz de Urbina J. (1977), Dictionnaire du Judéo-Espagnol, CSIC, Madrid.

Peters E. (1995), Journal Article Jewish History and Gentile Memory: The Expulsion of 1492, Vol. 9, No. 1, Springer.

Sloan D. (2007), Survival of an imperiled culture in the fifteenth and sixteenth centuries, Princetown University Press, New Jersey.

Sloan D. (2009), The Sephardic Jews of Spain and Portugal, McFarland \& Company Inc. Publishers, Jefferson, NC.

Tamar A. (2004), Words Are Better Than Bread, Ben-Gurion University Press and Ben-Zvi Institute, Negev.

\section{Internet sources}

http://ep00.epimg.net/descargables/2014/06/06/d2568a932335d0680fa9107ee72ef7a6.pdf http://www.reuters.com/article/2014/02/07/us-spain-jews-idUSBREA161GQ20140207 http://www.sephardifolklit.org/flsj/OLSJ https://www.youtube.com/watch?v=OVYE10U4SNc

www.um.es/tonosdigital/znum5/estudios/J-infierno.htm

http://www.tarbutsefarad.com/en/recortes-de-prensa/860--el-ladino-renace-de-sus-cenizas- ycautiva-a-generaciones-jovenes.html

http://www.nytimes.com/2014/03/20/world/europe/many-seek-spanish-citizenship-offeredto- sephardic-jews.html

http://politica.elpais.com/politica/2014/06/06/actualidad/1402043523 305436.html

http://www.chabad.org/library/article_cdo/aid/1085545/jewish/Will-Ladino-Rise-Again.htm 


\section{Streszczenie \\ Żydzi sefardyjscy i ích język: judeo-hiszpański czy ladino?}

Tekst opisuje najważniejsze aspekty języków, jakimi posługiwali się Żydzi sefardyjscy, ze szczególnym uwzględnieniem judeo-hiszpańskiego oraz ladino.

Cechy i etymologia języków, jak i subtelne różnice między nimi zostały ukazane na przykładach najważniejszych tekstów literackich, takich jak: Proverbios morales Santoba de Carrión, Regimiento de la vida rabiego Moshé Almosnino, Libro de mantenimiento de la alma Josepha Qaro, Dialoghi di Amore Guedaliá Ibn Yahiá, Pentateuco, Psalmy w tłumaczeniu Abrahama Asy czy Edykt z Alhambry o wygnaniu Żydów z 1492 roku.

Słowa kluczowe: Żydzi sefardyjscy, judeo-hiszpański, ladino 